Część I

\title{
KONCEPCJE
}



Adriana Biedroń

Akademia Pomorska w Slupsku

\section{PODŁUŻNE BADANIE ZDOLNOŚCI JĘZYKOWYCH JAKO KONCEPTU DYNAMICZNEGO}

\section{Longitudinal study of foreign language aptitude as a dynamic concept}

In contemporary literature foreign language ability is considered a dynamic concept, that is, subject to an evolutionary development in interaction with the environment and potentially trainable (Sternberg, 2002). Sternberg's Triarchic Theory of Human Intelligence is based on an assumption that abilities are forms of developing expertise. An important educational implication of this statement is that abilities are flexible and pliable rather than fixed and that they can be taught. The purpose of the paper is to present results from the first stage of a longitudinal study of foreign language aptitude on a sample of English philology students. The goal of this study, conducted in cooperation with a psychologist, is to analyze the students' cognitive abilities and establish whether they are subject to a dynamic change.

\section{Wstęp}

Artykuł dotyczy problemu analizy zdolności językowych (foreign language aptitude), jako pojęcia dynamicznego podlegającego zmianom na przestrzeni czasu u studentów języka obcego. W analizie badawczej przyjęto wieloaspektowe podejście do omawianego problemu, uwzględniające zarówno zdolności językowe, jak i niejęzykowe. Oznacza to, iż w badaniu wykorzystane zostaną zarówno narzędzia służące do badania zdolności językowych, jak narzędzia pomiarowe standardowo stosowane w psychologii, takie jak Skala inteligencji APIS-C, czy Kwestionariusz osobowości NEO-FFI McCrae i Costy, jako badań komplementarnych w stosunku do standardowych testów zdolności językowych. Badanie prowadzone jest przy wspó1- 
pracy z psychologiem. Rola psychologa polega w takim przypadku nie tylko na samym przeprowadzeniu testu do którego jest uprawniony, ale, przede wszystkim, na fachowej interpretacji wyników, zgodnie ze standardami i wiedzą teoretyczną.

W niniejszym artykule zaprezentowane zostaną wyniki z pierwszego etapu badania podłużnego przeprowadzonego na grupie 44 studentów filologii angielskiej i angielskiej z niemiecką. W przypadku analizy podłużnej zjawiska zdolności językowych, celem badania jest stwierdzenie, czy zdolności te podlegaja zmianom na przestrzeni czasu, konkretnie, czy wystapiły statystycznie istotne różnice pomiędzy pomiarami na przestrzeni 3 lat. Przy zastosowaniu zaawansowanych analiz statystycznych możliwe będzie ustalenie, czy ewentualna zmiana jest funkcją inteligencji, cech osobowości, zdolności językowych, pojemności pamięci roboczej i czy koreluje $z$ postępami w nauce.

Dynamika zdolności językowych jest pojęciem kontrowersyjnym. Tradycyjne pojmowanie zdolności językowych jako cech względnie stałych i niepodatnych na trening strategiczny, zostało zastapione tezą dynamicznego rozwoju zale-żnego od kontekstu nauki (Dörnyei, 2005; Grigorenko, Sternberg i Ehrman, 2000; Robinson, 2007), opartą na triadowej teorii inteligencji Sternberga (2002). Powyższa teza stanowi podstawę teoretyczną prezentowanego badania.

\section{Podstawowe pojęcia}

\subsection{Zdolności językowe}

Definicja zdolności językowej (foreign language aptitude) Johna B. Carrolla (1959, 1981) określa ją jako potencjalną możliwość nauczenia się języka obcego. Zarówno w klasycznym, jak i współczesnym pojmowaniu, zdolność językowa odnosi się do tempa nauki języków obcych, a nie do potencjalnej możliwości osiągnięcia sukcesu, tenże bowiem jest udziałem ludzi o różnych możliwościach intelektualnych i różnych profilach zdolności (por. Ehrman, 2008; Leaver, Ehrman i Shekhtman, 2005).

Carroll (1959) przedstawia zdolność językową jako składającą się z czterech komponentów:

- zdolność kodowania fonematycznego (phonemic coding ability), która warunkuje łatwość rozróżniania i imitowania dźwięków obcego języka;

- wrażliwość gramatyczna (grammatical sensitivity), będąca zdolnością identyfikacji funkcji gramatycznych pełnionych przez słowa w zdaniu;

- zdolność indukcyjnego (inductive language learning ability) uczenia się języka związaną z umiejętnością identyfikacji prawidłowości rządzących strukturą języka;

- pamięć (associative memory), która jest szczególnie ważna w nauce słownictwa w języku obcym.

Ostatnio wyłoniło się wiele nowych interpretacji tego pojęcia, z których szczególnie wartościowa wydaje się propozycja Skehana $(1998,2002)$ dzielącego ZJ na trzy komponenty odpowiadające etapom uczenia się języka obcego. Są to: zdol- 
ności fonetyczne, szczególnie istotne w pierwszym etapie nauki języka, zdolności analityczne, ważne w środkowej fazie nauki, oraz pamięć, powiązana z płynnościa mówienia pożądaną w zaawansowanej fazie nauki.

Wśród różnorodnych definicji i kategoryzacji zdolności językowych na uwage zasługują koncepcje osadzające to pojęcie w kontekście teorii i badań dotyczących struktury zdolności poznawczych i uznające współzależność czynników poznawczych (cognitive factors), afektywnych (affective factors), i konatywnych (conative factors) (motywacja) w realizacji potencjału poznawczego (Corno i inni, 2002; Robinson, 2002, 2007, 2009). Zdolność językowa, lub raczej zdolności językowe, (ZJ), to potencjał i gotowość do pracy nad specyficznym rodzajem zadania i w specyficznej sytuacji. Nie jest to zdolność homogeniczna i statyczna, lecz stanowi zespoły czynników (aptitude complexes - Robinson, 2007), wspó1działających w rozwiązywaniu zadań, którego efektem jest uczenie się. Bardzo ciekawą i kontrowersyjną koncepcją jest pojęcie dynamiki zdolności językowych, traktujące ten specyficzny rodzaj zdolności jako potencjalnie poddający się treningowi i rozwojowi w interakcji z kontekstem nauki języka obcego (Dörnyei, 2005; Grigorenko, Sternberg i Ehrman 2000; Robinson, 2007; Sternberg, 2002; Sternberg i Grigorenko, 2000).

\subsection{Triadowa Teoria Inteligencji Sternberga}

Sternberg jest autorem Triadowej Teorii Inteligencji (Triarchic Theory of Human Intelligence) (1998, 2002), która postuluje istnienie trzech grup zdolności: analitycznych (analytical), niezbędnych przy analizowaniu, ocenianiu, porównywaniu i odnajdywaniu różnic; twórçyych (creative), używanych przy tworzeniu i odkrywaniu, oraz praktycznych (practical), pozwalających na wdrażanie teorii w praktykę. Jednostka inteligentna, zdaniem Sternberga, potrafi skutecznie i trafnie oszacować swoje zdolności by wykorzystać atuty i zminimalizować deficyty. Zdolności szczególnie akcentowane w Triadowej Teorii to meta-procesy (planowanie, monitorowanie, ewaluacja); procesy związane z przyswajaniem wiedzy i działaniem (kodowanie informacji, wnioskowanie, porównywanie); radzenie sobie z nowością i automatyzacja czynności, a także adaptacja do środowiska. Sternberg jest twórca hipotezy mówiącej, że zdolności są formami rozwijającej się biegłości/umiejętności (1998) (expertise). To znaczy, że zdolności są konstruktami dynamicznymi i podlegającymi modyfikacji, a zatem można się ich nauczyć. Rozwój zdolności prowadzi do stania się ekspertem. Bycie ekspertem w jakiejś dziedzinie oznacza posiadanie głębokiej wiedzy deklaratywnej i proceduralnej, umiejętność wyboru skutecznych strategii, oraz wypracowanie zautomatyzowanych, efektywnych sposobów rozwiązywania problemów. Ponadto, ekspert posiada umiejętność trafnego przewidywania problemów i trafnej samooceny. Różnica pomiędzy osobą początkującą a ekspertem polega na celowej praktyce danej umiejętności. Jeżeli chodzi o zdolności twórcze, to eksperta charakteryzuje zdolność dostrzegania szczegółów zlekceważonych przez innych, podejmowanie intelektualnego ryzyka i wytrwałość w obliczu niepowodzenia. Twórcze myślenie zależy od czynni- 
ków indywidualnych, takich jak wiedza, style poznawcze, osobowość, motywacja, a także od środowiska Szczególną rolę Sternberg przypisuje inteligencji praktycznej, często ważniejszej w osiaganiu życiowego sukcesu, niż zdolności akademickie (por. Goleman, 1996).

Wyżej opisane zdolności/umiejętności przydają się w nauce obcego języka (Sternberg, 2002). Zdolności analityczne mają zastosowanie w rozumowaniu przez analogię, zwłaszcza u uczniów dorosłych, umiejętności planowania pozwalają na wybór skutecznej strategii uczenia się, kreatywność związana jest z umiejętnością radzenia sobie z nowością. Ta ostatnia umiejętność jest szczególnie cenna w nauce języka obcego pozwalając na adaptację w obcej kulturze. Podobnie, inteligencja praktyczna ułatwia asymilację w nowym środowisku, co wymaga umiejętności społecznych i interpersonalnych. Tak więc, Triadowa Teoria Inteligencji wykracza znacznie poza zakres czynników poznawczych, obejmując także czynniki osobowościowe, preferencje, a także interakcje ze środowiskiem.

Powyższa teoria stała się podstawą testu zdolności językowych CANALFT (Grigorenko, Sternberg i Ehrman, 2000). Analizując wyniki testu CANAL-FT, autorzy doszli do następujących wniosków: 1) wynik testu koreluje z ilością znanych języków, co dowodzi słuszności tezy, iż zdolności językowe można rozwijać; 2) zdolności językowe koreluja z inteligencja - czynniki te pokrywają się w znacznym stopniu; 3) należy uwzględnić czynnik pamięci roboczej w badaniach nad zdolnościami językowymi.

Najważniejszym postulatem kontrowersyjnej teorii Sternberga jest stwierdzenia, że zdolności językowe są modyfikowalne i można się ich nauczyć. Sternberg nie zakłada jednakże, że praktyka i doświadczenie mogą uczynić ekspertem każdego. Możliwość osiagnięcia doskonałości zawsze będzie zależała od czynników indywidualnych, które stanowią potencjał, ale i ograniczenie.

\subsection{Pamięć robocza}

Pamięć robocza (working memory) służy do czasowego przechowania i manipulacji informacjami w różnorodnych, złożonych zadaniach poznawczych (Baddeley, 2003; Conway i inni, 2008). Pamięć robocza, szczególnie jej komponent pętli artykulacyjnej (phonological loop), oraz ośrodek zarządzający zasobami uwagi (central executive) uważa się za czynniki decydujące o tempie i efektywności nauki języka obcego. Pamięć robocza traktuje się jako komponent zdolności językowej nie tylko w odniesieniu do tempa i skuteczności zapamiętywania nowych informacji, ale również w odniesieniu do szybkiego przełączania zasobów uwagi. Zdolność do szybkiego przełączania zasobów uwagi, zwracania uwagi na formę i zauważania różnicy pomiędzy własną produkcją językową a formą docelową, zależy od zdolności przetwarzania informacji werbalnej w postaci danych wejściowych w pamięci roboczej, której pojemność i efektywność decyduja o tempie uczenia się (Daneman i Carpenter, 1980; Dörnyei, 2005; Harrington i Sawyer, 1992; Mackey i inni., 2002; Miyake i Friedman, 1998; Osaka, Osaka i Groner., 1993; Robinson, 2002). 


\subsection{Współpraca z psychologiem}

Zbadanie wyżej omówionych cech wymaga podejścia interdyscyplinarnego, nie można bowiem rozpatrywać pojęcia zdolności językowych w oderwaniu od wiedzy z dziedziny psychologii. Etyka pracy wymaga korzystania z pomocy psychologa przy przeprowadzaniu testów psychologicznych. Testy takie mogą zakupić w Pracowni Testów Psychologicznych tylko dyplomowani psychologowie i tylko oni są uprawnieni do ich przeprowadzenia i interpretacji wyników. Kompetencje i zasady stosowania testów psychologicznych określa się w Standardach dla testów stosowanych w psychologii $i$ pedagogice (APA, 1985). Zdaniem wybitnego specjalisty w dziedzinie psychometrii, profesora Brzezińskiego „Test psychologiczny wyrwany z kontekstu teorii psychologicznej, która nadaje sens jego wynikowi, oraz z kontekstu teorii psychometrycznej, która określa stopień precyzji jego wyniku, nic nie znaczy; jest jedynie - mniej lub bardziej złożonym - zbiorem zdań, zadań arytmetycznych, obrazków, klocków itp." (Brzeziński i Hornowska, 2000, s. 404). Ponadto, współpraca z psychologiem może być źródłem cennego doświadczenia, mianowicie pozwala przyjąć perspektywę badacza innej dyscypliny. Psycholog kieruje się bardzo ściśle określonymi standardami przy planowaniu badania, czy konstrukcji narzędzia badawczego, jak również analizie wyników. Jego pomoc jest nieoceniona przy wyborze metody statystycznej, co może stanowić problem dla osoby, która nie przeszła szkolenia w tej dziedzinie.

\section{Studium}

\subsection{Uczestnicy}

Uczestnikami badania są studenci I roku Filologii Angielskiej (29) i Angielskiej z Niemiecką (15). Poziom językowy badanych na wstępie nie został precyzyjnie określony ze względu na ich dużą różnorodność w posługiwaniu się podsystemami językowymi, jak i niejednolite wymagania rekrutacyjne. Ogólnie, na specjalność Filologia Angielska przyjęto osoby, które zdały pisemną maturą z języka angielskiego na poziomie rozszerzonym (za minimalny wynik przyjęto około 60 punktów). Na specjalność Filologia Angielska z Niemiecką kryterium przyjęcia była zdana pisemna matura z języka angielskiego, oraz potwierdzona znajomość języka niemieckiego na dowolnym poziomie. Poziom studentów rozpoczynających studia był zatem wysoce zróżnicowany; zazwyczaj studenci reprezentowali wyższy poziom, jeżeli chodzi o umiejętności rozumienia ze słuchu i mówienia (B1/B1+), niż czytania i pisania (A2/B1). Egzamin końcowy z Praktycznej Nauki Języka Angielskiego (PNJA) przeprowadzony został na podstawie wcześniej ustalonych, jednolitych kryteriów na poziomie B2.

\subsection{Cele}

Pomimo ogólnie pozytywnego wyniku egzaminu z Praktycznej Nauki Języka Angielskiego (PNJA) (średnia 69,5 punktu na 100 możliwych), połowa osób (50\%), nie zdała egzaminu końcowego z tego przedmiotu: Filologia Angielska - 9 osób 
z 1 komponentu, 6 osób z 2 komponentów; Filologia Angielska z Niemiecką 2 osoby z 1 komponentu, 3 z 2 komponentów, 3 z 3 komponentów). W sumie komponentu mónienie nie zdało 12 osób; çytanie - 13 osób; pisanie - 9 osób; gramatykea - 6 osób. W związku z powyższym, powstaje pytanie natury dydaktycznej: co leży u podstaw tego problemu? Przyczyn można upatrywać w różnorodnych źródłach. Do analizy wybrano czynniki wewnętrzne:

- deficyty poznawcze: niska zdolność językowa, mała pojemność pamięci roboczej, lub niska inteligencja;

- cechy osobowości, takie jak niska otwartość na doświadczenia, nieumiejętność adaptacji do nowej sytuacji i zmiany starych nawyków; niska sumienność, wysoka neurotyczność i poziom lęku (wg modelu „Wielkiej Piątki" (McCrae i Costa, 2003).

Postawiono wstępną hipotezę badawcza, iż wszystkie z wyżej wymienionych czynników mogą mieć wpływ na wyniki w nauce. Podjęto próbę przeprowadzenia badania podłużnego na tej grupie w celu ustalenia, jakie czynniki koreluja z wynikiem w nauce. Pod uwagę wzięte zostały następujące zmienne: zdolności językowe, inteligencja, pamięć robocza, osobowość, oceny z PNJA.

W związku z podstawą teoretyczną i zdiagnozowanym problemem postawiono następujące cele badania:

- ustalenie, czy zdolności językowe, inteligencja, pamięć robocza i osobowość (wg modelu „Wielkiej Piątki”) korelują z wynikami w nauce na przestrzeni 3 lat;

- ustalenie, czy istnieją istotne różnice pomiędzy studentami dobrymi i słabymi w odniesieniu do wyżej wymienionych cech;

- ustalenie, czy zdolności językowe i pamięciowe podlegają dynamice, tzn., czy nastapił ich przyrost na przestrzeni 3 lat.

\subsection{Procedura}

Badanie w założeniu będzie trwało 3 lata (okres studiów licencjackich). W pierwszym etapie, obejmującym rok akademicki 2008/2009, zgromadzono dane dotyczące zdolności językowych, cech pamięci roboczej, oraz poziomu językowego studenta, oszacowanego na podstawie oceny z egzaminu z PNJA (czytanie, pisanie, mówienie, gramatyka, wynik ogólny). Rzetelność egzaminu ustalono metodą alfy Cronbacha na poziomach: mónienie: 0,708; csytanie: 0,758; pisanie: 0,732 ; gramatyka: 0,764; wynik całkowity: 0, 696 .

W drugim etapie, obejmującym rok akademicki 2009/2010 zmierzone zostaną osobowość i inteligencja badanych, oraz ponownie poziom językowy studenta, oszacowany na podstawie oceny z egzaminu z PNJA. Etap trzeci obejmie zebranie danych odnośnie poziomu językowego studenta, ponownie zmierzonego na podstawie końcowej oceny z egzaminu z PNJA, a także ponowne badanie testami zdolności językowych i pamięci roboczej. W kolejnych sekcjach przedstawione zostaną: hipoteza, narzędzia badawcze i wyniki dotyczące pierwszego etapu badania. 


\subsection{Hipoteza}

Hipoteza dotycząca pierwszego etapu badania jest następująca: „Istnieje pozytywna zależność pomiędzy zdolnościami językowymi i pojemnością pamięci, a wynikami w nauce języka obcego". Celem badania jest weryfikacja powyższej hipotezy.

\subsection{Narzędzia badawcze}

Test zdolności językowych w języku angielskim MLAT (Carroll i Sapon, 2002). Test mierzy zdolności językowe w 5 podtestach: zdolność zapamiętywania (pamięć krótkotrwała) - podtest I i V, zdolności fonetyczne - podtest II, słownictwo - podtest III, zdolność do nauki gramatyki - podtest IV.

Test Zdolności Językowych TZJ (Wojtowicz, 2006). Jest to polski test zdolności językowych, obejmujący 3 skale: dyskurs, słownictwo, gramatyka. Test zawiera między innymi takie zadania, jak wybranie najtrafniejszego streszczenia tekstu, tłumaczenie na sztuczny język, czy podanie synonimu lub antonimu do słowa. Zrezygnowano z podawania wyników stenowych, ze względu na brak norm dla grupy badanej.

\section{PRSPAN}

Jest to polska adaptacja testu RSPAN (Engle, i in., 1999) dokonana przez autorkę artykułu we współpracy z psychologiem. Test mierzy pojemność pamięci roboczej. Test składa się z 8 zestawów, zawierających od 3 do 10 zdań w języku polskim. $\mathrm{Na}$ końcu każdego zdania znajduje się wyraz niezwiązany ze zdaniem. Uczestnicy czytają zdania prezentowane w kolejności od najkrótszego do najdłuższego zestawu na ekranie monitora i starają się zapamiętać wyraz na końcu zdania, jednocześnie oceniając czy zdanie jest sensowne, czy bezsensowne. Za wynik ostateczny przyjmuje się skumulowaną liczbę wyrazów zapamiętanych we wszystkich próbach. Trafność testu oceniali sędziowie kompetentni (4 psychologów i 3 nauczycieli języka angielskiego). Zastosowano metodę ANOVA Friedmana i współczynnik zgodności Kendalla. Współczynnik Kendalla dla całego testu wyniósł 0,898; p <0,05. Trafność kryterialną oszacowano na podstawie korelacji ze standardowymi testami pamięci: MLAT 1: 0,45; MLAT 5: 0,47 (Carroll i Sapon, 2002); Symbole cyfr: 0,30; Powtarzanie cyfr: 0,49 (WAIS-R PL); p <0,05. Wyniki poszczególnych testów pamięciowych poddano analizie czynnikowej metoda głównych składowych. Analiza czynnikowa wykazała istnienie 1 czynnika wyjaśniającego $52 \%$ wariancji wyników. Rzetelność testu ustalono metodą test-retest (korelacja 0,89, p < 0,05), oraz alfy Cronbacha: 0,69 i alfy standaryzowanej: 0,76.

\subsection{Wyniki i interpretacja I etapu badania}

Średni wynik egzaminu z PNJA to 69,5 punktu. Najniższą średnią uzyskano z komponentu mówienie: 15,7 punktów (na 25 możliwych), natomiast wyniki czytania $(16,7)$ i pisania $(16,6)$, wykraczają niewiele ponad 15 punktów, co jest minimalnym 
wynikiem pozytywnym. Najlepiej wypadła gramatyka - 20 punktów. Wysokie odchylenie standardowe wyniku ogólnego PNJA świadczy o dużym zróżnicowaniu poziomu językowego grupy. Potwierdza to też duża rozbieżność pomiędzy wynikami minimalnymi i maksymalnymi (100\% różnicy). Podobne zróżnicowanie występuje w testach uzdolnień. Największe zróżnicowanie wyników odnotowano dla pamięci roboczej, gdzie różnica pomiędzy najwyższym i najniższym wynikiem wyniosła 35 punktów (na 52 możliwe), co znalazło odzwierciedlenie w wysokim odchyleniu standardowym. Podobną tendencję obserwujemy dla MLAT 1 i MLAT 5 - testów badających pamięć krótkotrwała. Wysokie odchylenie standardowe, które dowodzi, że grupa jest wysoce niejednorodna występuje także w przypadku wyniku całkowitego Testu Zdolności Językowych (TZJ). Małe odchylenia odnotowano dla MLAT 2, badającego uzdolnienia fonetyczne i analizy dyskursu w TZJ. Warto odnotować fakt, iż studenci uzyskali znacznie wyższe wyniki w teście językowym w języku angielskim, niż w języku polskim. Średnie wyniki dla MLATu są następujące: MLAT 1:72\%; MLAT 2:83\%; MLAT 5:73\%. Średnie wyniki TZJ: analiza dyskursu: $78 \%$; słownictwo: $64 \%$; gramatyka: $58 \%$; całkowity wynik TZJ: $65 \%$. Wynik testu pamięci roboczej jest przeciętny: 53\%. Zatem, analiza dyskursu i test fonetyczny okazały się najłatwiejsze dla większości studentów, najtrudniejszymi zaś test pamięci roboczej, gramatyka i słownictwo. Wyniki statystyk opisowych prezentowane są w tabeli 1 .

$\begin{array}{lrrrc} & \text { Średnia } & \text { Minimum } & \text { Maksimum } & \text { Odch.Std } \\ \text { Pamięć robocza } & 27,318 & 14,000 & 49,000 & 8,083 \\ \text { Mlat1 } & 30,840 & 2,000 & 42,000 & 8,902 \\ \text { Mlat2 } & 25,045 & 19,000 & 29,000 & 2,332 \\ \text { Mlat5 } & 17,613 & 7,000 & 24,000 & 5,388 \\ \text { Dyskurs } & 7,818 & 3,000 & 10,000 & 1,968 \\ \text { Słownictwo } & 11,454 & 4,000 & 18,000 & 3,406 \\ \text { Gramatyka1 } & 8,636 & 0,000 & 15,000 & 3,478 \\ \text { TZJ } & 27,909 & 16,000 & 41,000 & 6,418 \\ \text { Mówienie } & 15,727 & 9,000 & 25,000 & 3,539 \\ \text { Czytanie } & 16,693 & 10,500 & 23,000 & 3,452 \\ \text { Pisanie } & 16,636 & 11,000 & 23,000 & 2,989 \\ \text { Gramatyka2 } & 20,022 & 8,000 & 25,000 & 4,167 \\ \text { PNJA } & 69,488 & 46,000 & 92,000 & 10,633\end{array}$

Tabela 1: Statystyki opisowe dla studentów Filologii Angielskiej i Angielskiej z Niemiecką $(\mathrm{N}=44)$.

Uwaga: GRAMATYKA1 = wynik testu TZJ, GRAMATYKA2 = komponent PNJA, TZJ = Polski Test Zdolności Językowych - wynik całkowity, PNJA = Praktyczna Nauka Języka Angielskiego - wynik całkowity egzaminu końcowego.

Tabela 2 przedstawia korelację Pearsona poszczególnych zdolności oraz wyników egzaminu PNJA. Analiza korelacji nie wyjaśnia przyczyny zjawiska, a tylko 
pozwala stwierdzić, czy poszczególne wartości są ze sobą powiązane. Jak widać, wyniki egzaminu z PNJA, zarówno poszczególnych jego komponentów, jak i całości wykazuja korelacje z testami uzdolnień. Wynik całkowity PNJA koreluje w sposób istotny statystycznie z TZJ, co z jednej strony wskazuje na zależność poziomu opanowania języka obcego od zdolności językowych, z drugiej zaś strony dowodzi trafności narzędzia badawczego jakim jest TZJ. Obserwujemy też korelację PNJA z testami pamięci: roboczej (PRSPAN) i krótkotrwałej (MLAT 5). Najsłabszy komponent - mówienie koreluje pozytywnie z TZJ i z testem pamięci roboczej. Czytanie wykazuje korelacje z największą liczbą testów: pamięci roboczej, pamięci krótkotrwałej, TZJ (analizą dyskursu, gramatyką, wynikiem ogólnym). Nie koreluje natomiast z komponentem słownictwa, co może wydawać się zaskakujące, lecz wynika z zupełnie innych typów zadań w obu testach. Test czytania w PNJA polega na zrozumieniu i interpretacji czytanego tekstu, co w dużej mierze jest funkcja pojemności pamięci roboczej i inteligencji ogólnej. Element 'słownictwo' w TZJ testuje w znacznej mierze słowotwórstwo (znaczenia przyrostków), oraz zasoby leksykalne w języku ojczystym. Dwa pozostałe komponenty PNJA: gramatyka i pisanie wykazuja korelacje z TZJ.

Do badania wykorzystano tylko trzy części MLATu; 1 i 5 (pamięć), oraz 2 (fonetyka). Te części nie wymagaja biegłej znajomości języka, lecz bardzo podstawowego słownictwa i zaznajomienia $\mathrm{z}$ angielską fonetyką. Wybór ten podyktowany został poziomem językowym badanych. Testy MLAT wykazują słabe korelacje z PNJA. Tym niemniej, MLAT 5, będący klasycznym testem pamięci krótkotrwałej polegającym na szybkim zapamiętaniu słów w nieznanym języku koreluje pozytywnie z komponentem czytanie i wynikiem ogólnym PNJA.

\begin{tabular}{|c|c|c|c|c|c|c|c|c|c|c|c|c|c|}
\hline & PR & $\begin{array}{l}\text { ML } \\
\text { AT } \\
1 \\
\end{array}$ & $\begin{array}{l}\mathrm{ML} \\
\mathrm{AT} \\
2 \\
\end{array}$ & $\begin{array}{l}\mathrm{ML} \\
\mathrm{AT} \\
5 \\
\end{array}$ & $\begin{array}{l}\text { DYS } \\
\mathrm{KU} \\
\mathrm{RS} \\
\end{array}$ & $\begin{array}{l}\text { SŁO } \\
\text { WNI } \\
\text { CT }\end{array}$ & $\begin{array}{l}\text { GRA } \\
\text { MAT } \\
\text { YK1 }\end{array}$ & TZJ & $\begin{array}{l}\text { MÓ } \\
\text { WIE } \\
\text { NIE }\end{array}$ & $\begin{array}{l}\text { CZY } \\
\text { TAN } \\
\text { IE }\end{array}$ & $\begin{array}{l}\text { PIS } \\
\text { AN } \\
\text { IE }\end{array}$ & $\begin{array}{l}\text { GR } \\
\text { AM } \\
\text { AT2 }\end{array}$ & $\begin{array}{l}\mathrm{PN} \\
\mathrm{JA}\end{array}$ \\
\hline PR & 1,0 & ,11 & ,03 & ,28 &,- 04 & ,14 & ,21 & ,17 & ,47 & ,32 & ,20 &,- 08 &, 31 \\
\hline MLAT1 & ,11 & 1,0 & 20 & ,38 & ,06 & ,43 & ,55 &, 55 & ,19 & , 16 & ,15 & ,17 &, 23 \\
\hline MLAT2 &, 03 & ,20 & 1,0 &, 09 & ,29 & ,17 & ,26 &, 32 & , 15 & ,19 &, 09 & ,34 &, 25 \\
\hline MLAT5 & ,28 & ,38 &, 09 & 1,0 &,- 22 &, 05 & ,39 &, 17 & ,17 & ,36 &, 23 & ,12 &, 30 \\
\hline DY &,- 04 &, 06 & ,29 &,- 22 & 1,0 & ,28 & ,20 &, 56 & ,28 & ,31 &, 06 &, 07 &, 14 \\
\hline St & ,14 & ,43 & , 17 &, 05 & ,28 & 1,00 & ,30 &, 78 & ,34 & ,20 &, 39 & ,37 &, 46 \\
\hline GR1 & ,21 &, 55 &, 26 &, 39 & ,20 & ,30 & 1,0 &, 76 & ,30 &, 53 &, 37 & ,22 &, 45 \\
\hline TZJ & ,17 &, 55 & ,32 &, 17 & ,56 & ,78 & ,76 & 1,0 & ,43 & ,49 & ,42 & ,34 &, 53 \\
\hline MW & ,47 & , 19 & ,15 & , 17 & 28 & ,34 & ,30 & ,43 & 1,0 &, 55 & ,49 &, 35 &, 82 \\
\hline$C Z$ &, 32 & , 16 &, 19 &, 36 & ,31 & ,20 &, 53 & ,49 &, 55 & 1,0 & ,42 &, 03 & ,60 \\
\hline PS & ,20 & , 15 &, 09 &, 23 & ,06 & ,39 & ,37 &, 42 & ,49 &, 42 & 1,0 &, 47 &, 75 \\
\hline GR2 &,- 08 & ,17 &, 34 &, 12 &, 07 & ,37 &, 22 &, 34 &, 35 &, 03 &, 47 & 1,0 &, 66 \\
\hline PNJA & ,31 & ,23 & ,25 & ,30 & ,14 & ,46 & ,45 &, 53 & ,82 & ,60 & ,75 & ,66 & 1,0 \\
\hline
\end{tabular}

Tabela 2: Korelacje.

Oznaczone współczynniki korelacji są istotne z p <0,05; ( $N=44)$. 
Uwaga: $\mathrm{PR}=$ pamięć robocza, $\mathrm{DY}=$ analiza dyskursu $\mathrm{w}$ TZJ, SE $=$ test słownictwa $\mathrm{w}$ TZJ, GR1 = test gramatyki $\mathrm{w}$ TZJ, TZJ = Polski Test Zdolności Językowych - wynik całkowity, MW = PNJA - mówienie, CZ = PNJA - czytanie, PS = PNJA - pisanie, GR2 = PNJA - gramatyka, PNJA = Praktyczna Nauka Języka Angielskiego - wynik całkowity egzaminu końcowego.

Jak się okazuje, najłatwiejsze dla większości badanych komponenty testów zdolności: fonetyka i analiza dyskursu (wysokie wyniki i niskie odchylenia standardowe) w zasadzie nie korelują z wynikami komponentów i wynikiem ogólnym PNJA. W przypadku testów najtrudniejszych: pamięci roboczej, słownictwa, gramatyki i TZJ, korelacja występuje zarówno dla komponentów, jak i dla wyniku całkowitego PNJA.

\section{Wnioski}

$\mathrm{Na}$ podstawie wyżej przedstawionych wyników można wywnioskować, że wynik praktycznej nauki języka angielskiego może być powiązany ze zdolnościami językowymi mierzonymi testem w języku ojczystym (TZJ). Wynik tego testu koreluje z wszystkimi komponentami PNJA, co potwierdza hipotezę badawcza. Drugim źródłem problemu dla studentów może być nieefektywne działanie pamięci roboczej. Stosunkowo niski średni wynik w tym teście $(53 \%)$ w porównaniu do osób wielojęzycznych, który wynosi $78 \%{ }^{1}$, może być skutkiem problemu w zakresie procesów uwagi (central executive). Problem może dotyczyć przełączania zasobów uwagi i procesów hamowania, które to zdolności wymagane są w złożonych czynnościach poznawczych wymagających szybkiego przełączania zasobów uwagi z jednego zadania na drugie. Taki rodzaj podwójnego zadania stanowi na przykład mówienie w języku obcym, kiedy to po zrozumieniu i zakodowaniu komunikatu, należy szybko sformułować sensowną odpowiedź. Czytanie ze zrozumieniem również angażuje duże zasoby uwagi i pamięci (Daneman i Carpenter, 1980). Pamięć robocza wykazuje istotne korelacje z inteligencja (Conway i in., 2008), a ponieważ mówienie i czytanie stanowią najtrudniejsze komponenty dla studentów, zbadanie grupy pod tym kątem może stanowić kolejny krok w analizie problemu. Interesujących wniosków może dostarczyć badanie osobowości studentów. Czynnik otwartości na doświadczenie może powiedzieć wiele o ich otwartości intelektualnej i tolerancji niejednoznaczności. Wysoka neurotyczność, oznaczająca wysoki poziom lęku, mogłaby mieć wpływ na funkcjonowanie intelektualne. Z kolei czynnik sumienności może mieć bezpośrednie przełożenie na systematyczność i ilość wysiłku włożonego w naukę. Przeprowadzenie tychże testów wymaga współpracy z psychologiem, gdyż tylko ona umożliwia legalny dostęp do narzędzi badawczych, a także rzetelną analizę i interpretację wyników. Badanie podłużne na przestrzeni 3 lat studiów pozwoli na zgromadzenie danych dotyczących cech poznawczych i osobowościowych studentów i porównanie ich do postępów w nauce.

\footnotetext{
${ }^{1}$ Wyniki tego badania prezentowane były na konferencji dotyczącej różnic indywidualnych, zorganizowanej przez Uniwersytet Śląski w Szczyrku 28-30 maja, 2009.
} 


\section{BIBLIOGRAFIA}

Amerykańskie Towarzystwo Psychologiczne APA, 1985. Standardy dla testów stosowanych w psychologii i pedagogice, Biblioteka psychologa praktyka, tom 1. Warszawa: Pol. Tow. Psychol., Lab. Technik Diagnostycznych.

Baddeley, A.D. 2003. « Working memory and language: an overview ». Journal of communication disorders 36: 189-208.

Brzeziński, J., Hornowska, E. 2000. « Podstawowe metody badawcze - teoria i praktyka testowania » (w) Psychologia. Podrecznik akademicki, tom 1 (red. J. Strelau). Gdańsk: GWP.

Carroll, J.B. 1959. «Use of the Modern Language Aptitude Test in secondary schools ».Yearbook of the National Council on measurements used in education 16: 155-159.

Carroll, J.B. 1981. "Twenty-five years of research on foreign language aptitude » (w) Individual differences and universals in language learning aptitude (red. K. C. Diller). Rowley, M. A: Newbury House.

Carroll, J. B., Sapon S. 2002. Modern Language Aptitude Test. MLAT. Manual 2002 edition. N. Bethesda, Maryland: Second Language Testing, Inc.

Conway, A. R. A., Jarrold, Ch., Kane, M.J., Miyake, A., Towse, J. N. 2008. «Variation in working memory. An introduction » (w) Variation in working memory (red. A.R.A. Conway, Ch. Jarrold, M.J. Kane, A. Miyake, i J. N. Towse). Oxford: Oxford University Press.

Corno, L., Cronbach, L. J., Kupermintz, H., Lohman, D. F., Mandinach, E. B., Porteus, A. W., Talbert, J.E. 2002. «Remaking the concept of aptitude: Extending the legacy of Richard E. Snow ». Mahwah, NJ: Lawrence Erlbaum. International journal of bilingualism 11/4:391-409.

Daneman, M., Carpenter, P. 1980. «Individual differences in working memory and reading ». Journal of verbal learning and verbal behavior 19: 450-466.

Dörnyei, Z. 2005. The psychology of the language learner. Mahwah, NJ: Lawrence Erlbaum.

Ehrman, M.E. 2008. «Personality and good language learners ». (w) Lessons from good language learners (red. C. Griffiths). Cambridge: CUP.

Engle, R. W., Laughlin, J.E., Tuholski, S. W., Conway, A. R. A. 1999. « Working memory, short-term memory, and general fluid intelligence: a latent-variable approach ». Journal of experimental psychology: General, vol. 128/3: 309-331.

Goleman, D. 1996. Emotional Intelligence. New York: Bantam Books.

Grigorenko, E. L., Sternberg, R. J., Ehrman, M. E. 2000. «A theory based approach to the measurement of foreign language learning ability: the CANAL-F theory and test ». Modern language journal 84: 390-405.

Harrington, M., Sawyer, M. 1992. «L2 working memory capacity and L2 reading skill». Studies in second language acquisition 14: 25-38.

Leaver, B. L., Ehrman, R., Shekhtman, B. 2005. Achieving success in second language acquisition. Cambridge: CUP.

Mackey, A., Philip, J., Egi, T., Fujii, A., Tatsumi, T. 2002. «Individual differencesin 
working memory, noticing interactional feedback and L2 development » (w) Individual differences and instructed language learning (red. P. Robinson). Philadelphia: John Benjamins Publishing Company.

McCrae, R.R., Costa, P.T. 2003. Personality in adulthood: a five-factor theory perspective. $2^{\text {nd }}$ ed. New York: Guilford Press.

Miyake, A., Friedman, N. P. 1998. «Individual differences in second language proficiency: Working memory as language aptitude» (w) Foreign language learning (red. A. Healy i L. Bourne). Mahwah, NJ: Lawrence Erlbaum.

Osaka, M., Osaka, N., Groner, R. 1993. « Language-independent working memory: Evidence from German and French span tests ». Bulletin of the Psychonomic Society 31: $117-118$.

Robinson, P. 2002. "Learning conditions, aptitude complexes and SLA: A framework for research and pedagogy » (w) Individual differences and instructed language learning (red. P. Robinson). Philadelphia: John Benjamins Publishing Company.

Robinson, P. 2007. «Aptitudes, abilities, contexts, and practice» (w) Practice in second language (red. R. M. DeKeyser). Cambridge: CUP.

Robinson, P. 2009. «Individual differences, aptitude complexes, SLA processes and aptitude test development » (w) Studies in pedagogy and fine arts. New perspectives on individual differences in language learning and teaching, vol. 8. (red. M. Pawlak). Poznań-Kalisz: Faculty of Pedagogy and Fine Arts in Kalisz Adam Mickiewicz University in Poznań.

Skehan, P. 1998. A cognitive approach to language learning. Oxford: Oxford University Press.

Skehan, P. 2002. "Theorising and updating aptitude » (w) Individual differences and instructed language learning (red. P. Robinson). Philadelphia: John Benjamins Publishing Company.

Sternberg, R.J. 1998. "Abilities are forms of developing expertise ». Educational researcher, vol. 27/3: 11-20.

Sternberg, R. J. 2002. "The theory of successful intelligence and its implications for language aptitude testing » (w) Individual differences and instructed language learning (red. P. Robinson). Philadelphia: John Benjamins Publishing Company.

Sternberg, R.J., Grigorenko, E. L. 2000. Dynamic testing: The nature and measurement of learning potential. New York: CUP.

Wojtowicz, M. 2006. Test źdolności jezylkonych, TZJ .Warszawa: Pracownia Testów Psychologicznych PTP. 